\title{
High-resolution tropospheric carbon monoxide profiles retrieved from CrIS and TROPOMI
}

\author{
Dejian Fu ${ }^{1}$, Kevin W. Bowman ${ }^{1}$, Helen M. Worden ${ }^{2}$, Vijay Natraj ${ }^{1}$, John R. Worden ${ }^{1}$, Shanshan Yu ${ }^{1}$, \\ Pepijn Veefkind ${ }^{3,4}$, Ilse Aben ${ }^{5}$, Jochen Landgraf ${ }^{5}$, Larrabee Strow ${ }^{6}$, and Yong Han ${ }^{7}$ \\ ${ }^{1}$ NASA Jet Propulsion Laboratory, California Institute of Technology, Pasadena, California, USA \\ ${ }^{2}$ National Center for Atmospheric Research, Boulder, Colorado, USA \\ ${ }^{3}$ Royal Netherlands Meteorological Institute, Utrechtseweg, De Bilt, the Netherlands \\ ${ }^{4}$ Delft University of Technology, Department of Geoscience and Remote Sensing, Stevinweg 1, Delft, the Netherlands \\ ${ }^{5}$ SRON Netherlands Institute for Space Research, Sorbonnelaan, Utrecht, the Netherlands \\ ${ }^{6}$ University of Maryland, Baltimore, Maryland, USA \\ ${ }^{7}$ Center for Satellite Applications and Research, National Environmental Satellite, Data, and Information Service, \\ NOAA, College Park, Maryland, USA
}

Correspondence to: Dejian Fu (dejian.fu@jpl.nasa.gov)

Received: 23 December 2015 - Published in Atmos. Meas. Tech. Discuss.: 21 January 2016

Revised: 14 May 2016 - Accepted: 24 May 2016 - Published: 10 June 2016

\begin{abstract}
The Measurements of Pollution in the Troposphere (MOPITT) instrument is the only satellite-borne sensor in operation that uses both thermal (TIR) and nearinfrared (NIR) channels to estimate CO profiles. With more than 15 years (2000 to present) of validated multispectral observations, MOPITT provides the unique capability to separate $\mathrm{CO}$ in the lowermost troposphere (LMT, surface to $3 \mathrm{~km}(\sim 700 \mathrm{hPa}))$ from the free-tropospheric abundance. To extend this record, a new, hyper-spectral approach is presented here that will provide $\mathrm{CO}$ data products exceeding the capabilities of MOPITT by combining the shortwavelength infrared (SWIR, equivalent to the MOPITT NIR) channels from the TROPOspheric Monitoring Instrument (TROPOMI) to be launched aboard the European Sentinel 5 Precursor (S5p) satellite in 2016 and the TIR channels from the Cross-track Infrared Sounder (CrIS) aboard the Suomi National Polar-orbiting Partnership (Suomi NPP) satellite. We apply the MUlti-SpEctra, MUlti-SpEcies, Multi-SEnsors (MUSES) retrieval algorithm to quantify the potential of this joint $\mathrm{CO}$ product. $\mathrm{CO}$ profiles are retrieved from a single-footprint, full-spectral-resolution CrIS transect over Africa on 27-28 August 2013 coincident with significant biomass burning. Comparisons of collocated CrIS and MOPITT CO observations for the LMT show a mean difference of $2.8 \pm 24.9 \mathrm{ppb}$, which is well within the estimated mea-
\end{abstract}

surement uncertainty of both sensors. The estimated degrees of freedom (DOF) for $\mathrm{CO}$ signals from synergistic CrISTROPOMI retrievals are approximately 0.9 in the LMT and 1.3 above the LMT, which indicates that the LMT CO can be distinguished from the free troposphere, similar to MOPITT multispectral observations $(0.8$ in the LMT, and 1.1 above the LMT). In addition to increased sensitivity, the combined retrievals reduce measurement uncertainty, with $\sim 15 \%$ error reduction in the LMT. With a daily global coverage and a combined spatial footprint of $14 \mathrm{~km}$, the joint CrISTROPOMI measurements have the potential to extend and improve upon the MOPITT multispectral $\mathrm{CO}$ data records for the coming decade.

\section{Introduction}

Observations of tropospheric carbon monoxide $(\mathrm{CO})$ from space over the last decade have been exploited for monitoring air quality (e.g., Clerbaux et al., 2008a; Kar et al., 2010), quantifying CO emissions (e.g., Kopacz et al., 2009; Fortems-Cheiney et al., 2011), analyzing long-range transport of pollution (e.g., Heald et al., 2003; Edwards et al., 2006; Zhang et al., 2006), attributing sources and sinks of $\mathrm{CO}_{2}$ concentrations (e.g., Silva et al., 2013), and evaluat- 
Table 1. Satellite missions that measure tropospheric carbon monoxide.

\begin{tabular}{lccr|rrr}
\hline Mission & Nominal lifetime & $\begin{array}{c}\text { Years after its } \\
\text { design lifetime }\end{array}$ & $\begin{array}{r}\text { Spectral resolution } \\
\left(\mathrm{cm}^{-1}\right)\end{array}$ & $\begin{array}{r}\text { Footprint } \\
\text { size }\end{array}$ & $\begin{array}{r}\text { Swath } \\
\text { width }\end{array}$ \\
\cline { 2 - 7 } & Start-end & Year & TIR $^{\mathrm{a}}$ & $\mathrm{NIR}^{\mathrm{b}}$ & $\mathrm{km}^{2}$ & $\mathrm{~km}^{2}$ \\
\hline CrIS-TROPOMI & $2016-2023$ & 0 & $0.625^{\mathrm{c}}$ & 0.458 & $14 \times 14^{\mathrm{d}}$ & 2200 \\
MOPITT & $2000-2006$ & 9 & $\sim 0.04 \mathrm{eff}^{\mathrm{e}}$ & $\sim 0.25$ eff $^{\mathrm{e}}$ & $22 \times 22$ & 640 \\
CrIS & $2011-2026$ & 0 & $0.625^{\mathrm{c}}$ & $\mathrm{NA}$ & $\pi \times 441^{\mathrm{d}, \mathrm{f}}$ & 2200 \\
TES & $2004-2010$ & 5 & $0.06^{\mathrm{c}}$ & $\mathrm{NA}$ & $8 \times 5$ & 5 \\
AIRS & $2002-2008$ & 7 & $\sim 1.800$ & $\mathrm{NA}$ & $\pi \times 441^{\mathrm{d}, \mathrm{f}}$ & 1600 \\
TROPOMI & $2016-2023$ & 0 & $\mathrm{NA}$ & $\sim 0.458$ & $7 \times 7$ & 2600 \\
SCIAMACHY & $2002-2007$ & Terminated & NA & $\sim 0.485$ & $30 \times 120$ & 960 \\
IASI-A, B, C & $2006-2023$ & 0 & $0.25^{\mathrm{c}}$ & $\mathrm{NA}$ & $\pi \times 576^{\mathrm{f}}$ & 2200 \\
ACE-FTS & $2003-2005$ & 10 & 0.02 & 0.02 & NA & NA \\
\hline
\end{tabular}

${ }^{a}$ First fundamental band of carbon monoxide, centered around $4.6 \mu \mathrm{m}$ in the thermal infrared. ${ }^{\mathrm{b}}$ First overtone band of carbon monoxide, centered around $2.3 \mu \mathrm{m}$ in the near infrared. ${ }^{\mathrm{c}}$ Specified values are the spectral resolution without apodization. ${ }^{\mathrm{d}}$ The spatial resolution of data products from this work are 9 times higher than the existing operational CrIS and AIRS data products, since we use single-footprint CrIS L1B radiances in the retrievals, instead of cloud-cleared radiances. ${ }^{\mathrm{e}}$ MOPITT uses gas filter correlation radiometry (GFCR) with estimated effective spectral resolution. ${ }^{\mathrm{f}}$ Estimated nadir footprint sizes of AIRS, CrIS, and IASI measurements since (1) the sensors have circular fields of view and (2) the operational retrieval algorithm uses cloud-cleared radiances produced using multiple single-footprint L1B spectra (nine spectra for AIRS or CrIS, four spectra for IASI). ${ }^{g}$ The measurements from SCIAMACHY (SCanning Imaging Absorption SpectroMeter for Atmospheric CHartographY) ceased in 2012. ${ }^{\mathrm{h}}$ The IASI-A and IASI-B instruments are on board MetOp-A (launched in 2006) and MetOp-B (launched in 2012) satellites. The third IASI instrument will be on board MetOp-C with an estimated launch date in 2018. MetOp-A and MetOp-B satellites are in a sun-synchronous, $817 \mathrm{~km}$ altitude orbit with a 09:30 LT Equator-crossing time (ascending node), a few hours earlier than that of S5-P satellite. The IASI CO data product is retrieved from the $4.6 \mu \mathrm{m}$ band (George et al., 2009). ${ }^{\mathrm{i}}$ ACE-FTS on board the Canadian satellite SCISAT, operating in the solar occultation measurement mode at sunrise and sunset, provides high-vertical-resolution (3-4 km) profiles in the altitude region from the middle troposphere to the thermosphere for over 30 atmospheric trace gases as well as the meteorological variables of temperature and pressure (Bernath et al., 2005; Boone et al., 2005; Fu et al., 2007, 2009; Allen et al., 2009). The operational ACE-FTS CO data product is jointly retrieved from the 2.3 and $4.6 \mu \mathrm{m}$ bands (Clerbaux et al., 2008b).

ing chemical transport models and decadal trends in atmospheric composition (e.g., Shindell et al., 2006; Worden et al., 2013a). The Measurements Of Pollution In The Troposphere (MOPITT) instrument, which is on the Earth Observing System (EOS)-Terra platform, has acquired more than 15 years (2000 to present) of validated global CO observations (Emmons et al., 2007, 2009; Deeter et al., 2013, 2014). MOPITT is equipped with gas filter correlation radiometers (Drummond, 1992) measuring both CO first fundamental $(4.6 \mu \mathrm{m})$ and overtone bands $(2.3 \mu \mathrm{m})$. The synergy of the $\mathrm{CO}$ first fundamental band in the thermal infrared (TIR) and overtone band in the near infrared (NIR) provides an unprecedented sensitivity to probe $\mathrm{CO}$ in the lowermost troposphere (LMT, surface to $3 \mathrm{~km}$ ) (Worden et al., 2010, 2013b). This unique multispectral capability of MOPITT is not available from any single sensor on existing satellites that depend on a single spectral band, e.g., AIRS (Atmospheric Infrared Sounder) on EOS-Aqua (McMillan et al., 2005; Warner et al., 2007), TES (Tropospheric Emission Spectrometer) on EOS-Aura (Rinsland et al., 2006), IASI (Infrared Atmospheric Sounding Interferometer) on MetOpA and MetOp-B (George et al., 2009), and SCIAMACHY on Envisat (de Laat et al., 2007). Retrieval sensitivity to the LMT is critical for the operational use of satellite data in air quality, climate, and carbon applications, motivating the multispectral retrieval approach for a variety of species, including $\mathrm{O}_{3}$ and $\mathrm{CO}$ (Landgraf and Hasekamp, 2007; Worden et al., 2010, 2013a, b; Cuesta et al., 2013; Fu et al., 2013; Luo et al., 2013).

All NASA space missions capable of measuring atmospheric CO concentrations have passed their nominal lifetime by years (Table 1). The European Space Agency (ESA) Sentinel 5 Precursor (S5p) TROPOspheric Monitoring Instrument (TROPOMI), which is expected to launch in 2016 into an afternoon orbit behind the Suomi National Polarorbiting Partnership (Suomi NPP) satellite, has only NIR channels for $\mathrm{CO}$ measurements. The Cross-track Infrared Sounder (CrIS) aboard the Suomi NPP satellite is a TIR sensor operating since 28 October 2011 and providing measurements of full-spectral-resolution radiances for all three spectral bands since 4 December 2014 (Han et al., 2015). The constellation of Suomi NPP and ESA S5p provides a unique set of collocated observations, which could extend the EOS MOPITT multispectral CO data products with significant improvements on spatial resolution and coverage (Table 1). This multispectral retrieval algorithm could also be applied to the future joint Sentinel-5 UVNS-IASI-NG observations from MetOp Second Generation satellites (Veefkind et al., 2012; Crevoisier et al., 2014), which are anticipated in the time period of 2022-2045.

The MUlti-SpEctra, MUlti-SpEcies, Multi-SEnsors (MUSES) retrieval algorithm has a generic design that incorporates hyperspectral forward model radiances from multiple sensors in a joint optimal estimation retrieval 
algorithm. MUSES has been applied to joint TES-OMI ozone retrievals (Fu et al., 2013; Worden et al., 2013b) using measured TIR/UV spectral radiances and joint TES-MLS CO retrievals (Luo et al., 2013) using measured TIR/microwave spectral radiances. In this paper, for the first time we describe the MUSES retrieval algorithm, which is capable of combining the TROPOMI and CrIS spectral radiances to produce atmospheric $\mathrm{CO}$ volume mixing ratio (VMR) profiles with a vertical resolution that improves upon the EOS-Terra MOPITT multispectral CO data products. This multispectral observation strategy offers two significant advantages relative to traditional single-band measurements: enhanced sensitivity to composition changes especially in the LMT, and reduced measurement uncertainty.

The paper is organized as follows: Sect. 2 describes the characteristics of CrIS-TROPOMI measurements and the pairing strategy. Section 3 describes the MUSES retrieval algorithm, samples of retrievals using CrIS fullspectral-resolution, single-footprint measurements, comparisons of collocated CrIS and MOPITT observations, and estimated characteristics of synergistic CrIS-TROPOMI retrievals. Conclusions are presented in Sect. 4.

\section{CrIS and TROPOMI}

CrIS is on the Suomi NPP satellite in a near-polar, sunsynchronous, $828 \mathrm{~km}$ altitude orbit with a 13:30 LT Equatorcrossing time (ascending node) and has been operational since 28 October 2011. TROPOMI will be on the ESA S5p satellite, planned for launch in 2016 with a design lifetime of 7 years (Table 1). S5p will fly within approximately 5 min of Suomi NPP, which enables collocated observations of atmospheric composition (cloud, aerosol, temperature, and trace gases) and surface properties (albedo, emissivity, and skin temperature), thus building upon the success of the "A-Train" constellation of Earth observation satellites.

CrIS is a Fourier transform spectrometer that measures the TIR radiances emitted by the Earth's surface and transmitted through atmospheric gases and particles in three spectral bands, including the long-wave IR band 1 (648.75-1096.25 $\left.\mathrm{cm}^{-1}\right)$, the mid-wave IR band 2 (1208.75$\left.1751.25 \mathrm{~cm}^{-1}\right)$, and the short-wave IR band $3(2153.75$ $2551.25 \mathrm{~cm}^{-1}$ ) (Han et al., 2013, 2015; Strow et al., 2013a, b; Tobin et al., 2013; Wang et al., 2013). It was intended as the operational successor to the AIRS instrument on the Aqua platform (Aumann et al., 2003; Pagano et al., 2003). The typical signal-to-noise ratio (SNR) of a CrIS measurement is about 800:1 in the spectral region of interest for CO. CrIS is a cross-track scanning instrument, whose full spectral resolution is $0.625 \mathrm{~cm}^{-1}$, providing measurements with daily global coverage (Table 1). Currently, the operational Level-1B products provide full spectral resolution only for the long-wave IR band 1 for the entire lifetime of the mission (Han et al., 2013). The full-resolution $\left(0.625 \mathrm{~cm}^{-1}\right)$ spectral radiance products for band 2 (was $1.25 \mathrm{~cm}^{-1}$ ) and band 3 (was $2.5 \mathrm{~cm}^{-1}$ ) have been available since 4 December 2014 (Han et al., 2015). Ground pixels have a diameter of $14 \mathrm{~km}$ at nadir. CrIS atmospheric measurements in the 2155$2209 \mathrm{~cm}^{-1}$ spectral region - nearly identical to observations of MOPITT TIR channels - include high-density absorption features of the strongest fundamental band of $\mathrm{CO}$ and minor absorption from interfering species, providing sensitivity for estimating the atmospheric $\mathrm{CO}$ concentration. It is worth noting that Gambacorta et al. (2014) found that the information content present in the $\mathrm{CO}$ retrievals improves up to one order of magnitude upon switching from spectral resolution of $2.5 \mathrm{~cm}^{-1}$ to the full spectral resolution of $0.625 \mathrm{~cm}^{-1}$ (starting from 4 December 2014).

TROPOMI will provide daily global coverage owing to its wide swath across track (Table 1). It is a nadir-viewing push broom imaging spectrometer that measures backscattered and reflected sunlight covering the 270-500, 675-725, $725-775$, and $2305-2385 \mathrm{~nm}\left(4193-4338 \mathrm{~cm}^{-1}\right)$ spectral regions. Its atmospheric measurements in the $2.3 \mu \mathrm{m}$ band nearly identical to observations of NIR channels of SCIAMACHY and MOPITT - include high-density absorption features of the overtone band of $\mathrm{CO}$, providing sensitivity for estimating the CO total column average VMR. The module of the spectral band at $2.3 \mu \mathrm{m}$ has a spectral resolution of $0.25 \mathrm{~nm}$ and a spectral sampling rate of about 2.0-2.5 detector elements per FWHM (full width at half maximum) (Veefkind et al., 2012). The ground pixel size of its CO measurements at the nadir position is $7 \times 7 \mathrm{~km}^{2}$, which yields a spatial resolution about 10 times higher than the Terra MOPITT $\left(22 \times 22 \mathrm{~km}^{2}\right)$ mission (Table 1). Within the spectral region of interest, the minimum spectral SNR of a single TROPOMI measurement is $120: 1$ in the continuum around $2310 \mathrm{~nm}\left(4329 \mathrm{~cm}^{-1}\right)$, specified for a scene with a surface albedo of $5 \%$ and solar zenith angle of $70^{\circ}$ (Veefkind et al., 2012).

In order to match the CrIS footprint size, our retrieval algorithm will average four adjacent pixels of TROPOMI prior to the spectral fittings. Hence, the effective SNR of TROPOMI measurements for the synergistic retrievals will be greater than $240: 1$. The joint CrIS-TROPOMI spatial resolution will be $14 \times 14 \mathrm{~km}^{2}$ at the nadir position, about 2.5 times higher than that of the MOPITT mission (Table 1). MUSES algorithm uses single-footprint CrIS L1B radiances into the retrievals, leading to the 9-times-smaller footprint size (Table 1) than that of operational algorithm (Gambacorta et al., 2014).

Daytime ascending node CO retrievals are available from TROPOMI and CrIS, whereas nocturnal descending node CO depends exclusively on CrIS. The daily spatial sampling of the joint CrIS-TROPOMI measurements is more than 8 times better than that of Terra MOPITT since CrISTROPOMI measurements have a $\sim 3.5$-times-wider swath and 2.5-times-finer ground pixel size compared to MOPITT (Table 1). After performing the temporal and spatial matches 
among CrIS-TROPOMI measurements, the distances between matched CrIS-TROPOMI observations in the nadir direction are within $3 \mathrm{~km}$ - smaller than the pixel sizes of both instruments. The associated temporal differences are within 5 min. In general, these spatial and temporal separations are small compared to the scales of variability anticipated for $\mathrm{CO}$ and could be neglected. Over complex source regions, such as urban areas, the special treatments on achieving perfect spatial match might be necessary.

\section{Retrieval algorithm, sample results, and retrieval characteristics}

This section describes the MUSES algorithm for synergistic retrievals of $\mathrm{CO}$ profiles (Sect. 3.1), sample retrievals when only using CrIS measurements (Sect. 3.2), and synthetic joint CrIS-TROPOMI CO retrievals to assess the characteristics of improved tropospheric CO profiling when combining TIR and NIR observations (Sect. 3.3).

\subsection{MUSES retrieval algorithm for producing joint TROPOMI and CrIS carbon monoxide volume mixing matrix profile data products}

The MUSES retrieval algorithm is based upon the optimal estimation (OE) method (Rodgers, 2000). OE combines a priori knowledge, which includes both a mean state and covariance of the atmospheric state, and the measurements to infer the atmospheric state. The $\mathrm{OE}$ algorithm computes the best-estimate state vector $\hat{\boldsymbol{x}}$, which represents the concentration of atmospheric trace gases and ancillary parameters, by minimizing the following cost function:

$C(\boldsymbol{x})=\left\|\boldsymbol{x}-\boldsymbol{x}_{\mathrm{a}}\right\|_{\mathbf{S}_{\mathrm{a}}^{-1}}^{2}+\left\|\boldsymbol{L}_{\mathrm{obs}}-\boldsymbol{L}_{\mathrm{sim}}\right\|_{\mathbf{S}_{\epsilon}^{-1}}^{2}$.

Equation (1) is a sum of quadratic functions representing Euclidean norm $\left(\|\boldsymbol{b}\|_{\mathbf{A}}^{2}=\boldsymbol{b}^{\mathrm{T}} \boldsymbol{a} \boldsymbol{b}\right)$, with the first term accounting for the difference between the retrieval vector $\boldsymbol{x}$ and a priori state $\boldsymbol{x}_{\mathrm{a}}$, inversely weighted by the a priori matrix $\mathbf{S}_{\mathrm{a}}$, and with the second term representing the difference between the observed $\boldsymbol{L}_{\text {obs }}$ and simulated $\boldsymbol{L}_{\text {sim }}$ radiance spectra inversely weighted by the measurement error covariance matrix $\mathbf{S}_{\epsilon}$.

Under the assumption that measurement error between TROPOMI and CrIS is uncorrelated, Eq. (1) can be written as

$$
\begin{aligned}
C(\boldsymbol{x})= & \left\|\boldsymbol{x}-\boldsymbol{x}_{\mathrm{a}}\right\|_{\mathbf{S}_{\mathrm{a}}^{-1}}^{2} \\
& +\underbrace{\left\|\boldsymbol{L}_{\mathrm{Obs} \_\mathrm{TROPOMI}}-\boldsymbol{L}_{\text {sim_TROPOMI }}\right\|_{\mathbf{S}_{\epsilon_{-} \text {TROPOMI }}^{2}}}_{\text {TROPOMI }} \\
& +\underbrace{\left\|\boldsymbol{L}_{\mathrm{obs} \_\mathrm{CrIS}}-\boldsymbol{L}_{\text {sim_CrIS }}\right\|_{\mathbf{S}_{\epsilon-\mathrm{CrIS}}^{-1}}^{2}}_{\text {CrIS }}
\end{aligned}
$$

The joint retrieval algorithm iteratively updates the state vector based upon a trust-region Levenberg-Marquardt opti- mization algorithm to minimize the cost function in Eq. (2) (Rodgers, 2000; Bowman et al., 2006):

$$
\boldsymbol{x}_{i+1}=\boldsymbol{x}_{i}+[\mathbf{S}_{\mathrm{a}}^{-1}+\underbrace{\mathbf{K}_{\mathrm{TROPOMI}}^{\mathrm{T}} \mathbf{S}_{\epsilon \_\mathrm{TROPOMI}}^{-1} \mathbf{K}_{\mathrm{TROPOMI}}}_{\text {TROPOMI }}+
$$

$$
\begin{aligned}
& \underbrace{\mathbf{K}_{\mathrm{CrIS}}^{\mathrm{T}} \mathbf{S}_{\epsilon_{-} \mathrm{CrIS}}^{-1} \mathbf{K}_{\mathrm{CrIS}}}_{\text {CrIS }}]^{-1} \times\left[\mathbf{S}_{\mathrm{a}}^{-1}\left(\boldsymbol{x}_{\mathrm{a}}-\boldsymbol{x}_{i}\right)+\right. \\
& \underbrace{\mathbf{K}_{\text {TROPOMI }}^{\mathrm{T}} \mathbf{S}_{\epsilon-\mathrm{TROPOMI}}^{-1} \Delta \boldsymbol{L}_{\mathrm{TROPOMI}}}_{\text {TROPOMI }}+\underbrace{\mathbf{K}_{\mathrm{CrIS}}^{\mathrm{T}} \mathbf{S}_{\epsilon_{-} \mathrm{CrIS}}^{-1} \Delta \boldsymbol{L}_{\mathrm{CrIS}}}_{\text {CrIS }}],
\end{aligned}
$$

where $\mathbf{K}$ is the Jacobian matrix representing sensitivity of spectral radiances to the atmospheric state and $\Delta \boldsymbol{L}$ is the difference between observed and simulated spectral radiances.

To simulate thermal infrared spectral radiances $\boldsymbol{L}_{\text {sim_CrIS }}$ and Jacobians $\mathbf{K}_{\mathrm{CrIS}}$, the joint CrIS and TROPOMI algorithm incorporates the forward model of the TES operational algorithm (Bowman et al., 2006; Clough et al., 2006), with CrIS specifications (spectral range, resolution, SNRs, and viewing geometry) obtained from CrIS L1B data products. In the NIR region, we use the Vector Linearized Discrete Ordinate Radiative Transfer (VLIDORT) model (Spurr, 2006; Spurr et al., 2008), with the specification for TROPOMI measurements (spectral range, resolution, SNRs) described in Veefkind et al. (2012), to compute the spectral radiances and Jacobians. The characteristics of joint CrIS-TROPOMI CO retrievals will be illustrated in Sect. 3.3.

The joint TROPOMI and CrIS retrievals start with the list of the fitting parameters, a priori values, and a priori variance shown in Table 2. In addition to the initial guess for the trace gas concentration $\left(\mathrm{CO}, \mathrm{H}_{2} \mathrm{O}, \mathrm{CH}_{4}\right.$, and $\left.\mathrm{N}_{2} \mathrm{O}\right)$, the initial guess for auxiliary parameters used in the simulation of CrIS radiances (including temperature profile, surface temperature and emissivity, cloud extinction and top pressure) is also retrieved from CrIS radiances in order to take into account their spectral signatures in the $\mathrm{CO}$ spectral regions.

When the clouds travel across its field of viewing, a space sensor for atmospheric composition measurements often faces the challenge of obtaining high-precision and highaccuracy measurements of the trace gas vertical distribution due to the possible interfering among retrieval parameters. The MUSES algorithm uses single-footprint CrIS L1B radiances in the retrievals, leading to the 9-times-smaller footprint size (Table 1) than that of operational algorithm (Gambacorta et al., 2014), reducing the impacts of cloud interference on trace gas retrievals. In addition, the MUSES algorithm has been designed to utilize the information from multiple satellites that provide collocated high-quality cloud measurements. The high-resolution Visible Infrared Imaging Radiometer Suite (VIIRS) aboard Suomi NPP will provide 
Table 2. List of parameters in state vector.

\begin{tabular}{|c|c|c|c|c|}
\hline Case selection $^{\mathrm{a}}$ & Fitting parameters & $\begin{array}{l}\text { Number of } \\
\text { parameters }\end{array}$ & A priori & A priori variance \\
\hline CrIS-TROPOMI, CrIS, TROPOMI & $\mathrm{CO}$ at each pressure level & 14 & MOZART- $3^{\mathrm{b}}$ & MOZART-3 \\
\hline CrIS-TROPOMI, CrIS & $\mathrm{N}_{2} \mathrm{O}$ at each pressure level & 25 & MOZART-3 & MOZART-3 \\
\hline CrIS-TROPOMI, CrIS, TROPOMI & $\mathrm{CH}_{4}$ at each pressure level & 25 & MOZART-3 & MOZART-3 \\
\hline CrIS-TROPOMI, CrIS & Surface temperature & 1 & GEOS-5 & $0.5 \mathrm{~K}$ \\
\hline CrIS-TROPOMI, CrIS & Cloud extinctiong & 3 & Initial BT difference & $300 \%$ \\
\hline CrIS-TROPOMI, CrIS & Cloud top pressure $\mathrm{g}$ & 1 & $500 \mathrm{mbar}$ & $100 \%$ \\
\hline CrIS-TROPOMI, TROPOMI & $\begin{array}{l}\text { Gaussian parameters of optical } \\
\text { depth profile for ice cloud }\end{array}$ & 3 & {$[0.0125,0.30,0.04]^{\mathrm{i}}$} & {$[7.4,0.2,0.01]^{\mathrm{i}}$} \\
\hline CrIS-TROPOMI, TROPOMI & $\begin{array}{l}\text { Gaussian parameters of optical } \\
\text { depth profile for water cloud }\end{array}$ & 3 & {$[0.0125,0.75,0.10]^{\mathrm{i}}$} & {$[7.4,0.4,0.01]^{\mathrm{i}}$} \\
\hline CrIS-TROPOMI, TROPOMI & Surface albedo zero-order term & 1 & from Spectra ${ }^{k}$ & 0.2 \\
\hline CrIS-TROPOMI, TROPOMI & Surface albedo first-order term & 1 & 0 & $0.0005 \mathrm{~cm}^{-1}$ \\
\hline CrIS-TROPOMI, TROPOMI & Radiance/irradiance wavelength shifts & 2 & 0 & $0.5 \mathrm{~cm}^{-1}$ \\
\hline
\end{tabular}

a The parameters are included in the retrievals for different cases (CrIS only, TROPOMI only, and joint CrIS-TROPOMI). ${ }^{\mathrm{b}}$ Model for OZone and Related chemical Tracers (MOZART)-3 (Brasseur et al., 1998; Park et al., 2004). ${ }^{\mathrm{c}}$ Goddard Earth Observing System, version 5 (GEOS-5) (Rienecker et al., 2008). ${ }^{\mathrm{d}}$ National Center for Environmental Prediction (NCEP) reanalysis (Kalnay et al., 1996). ${ }^{\mathrm{e}}$ Retrievals over land; spectral surface emissivity is included. ${ }^{\mathrm{f}}$ Global infrared land surface emissivity database at University of Wisconsin-Madison (UOW-M) (Seemann et al., 2008). ${ }^{g}$ For cloud treatment in TIR spectral region, we adopt the approach used in the TES Level-2 full-physics retrieval algorithm (Kulawik et al., 2006; Eldering et al., 2008). ${ }^{\mathrm{h}}$ For cloud treatment in NIR spectral region, we adopt the approach used in the OCO-2 Level-2 full-physics retrieval algorithm (p. 28-31, 44-45 in Boesch et al., 2015). The wavelength-dependent optical property would be scaled to that of TROPOMI. ${ }^{\mathrm{i}}$ Gaussian parameters represent the total optical depth, peak altitude, and profile width. The peak altitude and profile width are normalized to the pressure at surface. ${ }^{j}$ Modern Era Retrospective analysis for Research and Applications aerosol reanalysis (MERRAero) climatology (2009-2010) (Rienecker et al., 2011; Buchard et al., 2015). ${ }^{\mathrm{k}}$ The surface is assumed to be Lambertian with a variable slope in wavelength to the albedo, such that the albedo can vary linearly across the spectral band. A priori value of surface albedo for zero-order term are estimated from the measured continuum radiances, using the following equation: $A=\frac{\pi I}{\mu_{0} I_{0}}$, where $I$ is the measured Earth shine radiance in the continuum, $I_{0}$ is the solar continuum spectral irradiance, and $\mu_{0}$ is the cosine of the solar zenith angle.

access to high-spatial-resolution visible and IR information that can be used in quantifying cloud impact. This convoy enables cloud prescreening using VIIRS cloud products (Platnick et al., 2013), which is a scanning radiometer on the Suomi NPP satellite. This cloud prescreening improves the efficiency of data processing and the quality of the retrieved profiles. Cloudy scenes for the CrIS geometry $(\sim 14.0 \mathrm{~km} \mathrm{di-}$ ameter at nadir) will be characterized using the mature infrared cloud forward modeling techniques used in the TES retrievals (Kulawik et al., 2006; Eldering et al., 2008). For the cloud and aerosol radiative modeling within the field of view (FOV) of the TROPOMI sensor, we will adopt the algorithm that has been used in the production of Orbiting Carbon Observatory 2 (OCO-2) version 6 Level-2 standard products (Boesch et al., 2015). We will retrieve the Gaussian parameters that represent the optical depth profiles for water/ice clouds and the top two aerosols specified by the Modern Era Retrospective analysis for Research and Applications aerosol reanalysis (MERRAero) climatology (2009-2010) (Table 2). We will use VIIRS Level-2 products of surface temperature (Hook et al., 2012) and cloud property (cloud fraction, cloud optical thickness, and cloud top pressure; Baker, 2011a, b, 2012) as a priori information to retrieve ancillary parameters.

Optimal estimation theory provides tools to characterize the retrievals, e.g., vertical resolution/sensitivity and uncertainty. The averaging kernel matrix (A) and error covariance (S) can be calculated as follows (Rodgers, 2000):

$\mathbf{A}=\mathbf{G K}$,

$\mathbf{S}=(\mathbf{I}-\mathbf{A}) \mathbf{S}_{\mathrm{a}}\left(\mathbf{I}-\mathbf{A}^{\mathrm{T}}\right)+\mathbf{G} \mathbf{S}_{\epsilon} \mathbf{G}^{\mathrm{T}}$,

where $\mathbf{I}$ is a unitary matrix; $\mathbf{S}_{\mathrm{a}}$ is the a priori covariance matrix of the full retrieved state, which contains both atmospheric and auxiliary parameters; $\mathbf{S}_{\epsilon}$ is the measurement noise covariance; and $\mathbf{G}$, the gain matrix, can be written as the following equation:

$\mathbf{G}=\left(\mathbf{K}^{\mathrm{T}} \mathbf{S}_{\epsilon}^{-1} \mathbf{K}+\mathbf{S}_{\mathrm{a}}^{-1}\right)^{-1} \mathbf{K}^{\mathrm{T}} \mathbf{S}_{\epsilon}^{-1}$ 


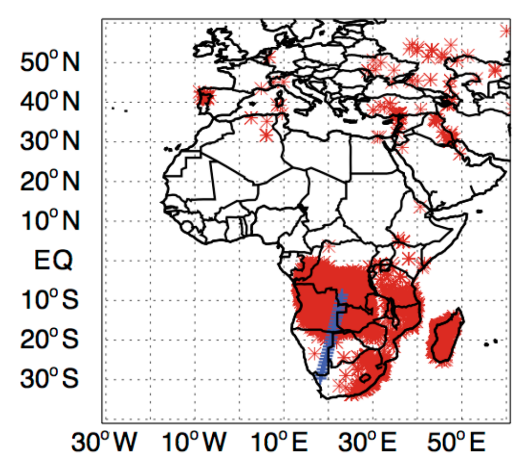

Figure 1. Collocated Suomi NPP CrIS measurements (blue cross) over Africa on 28 August 2013 and Terra MOPITT observations on 27 August 2013. The red stars represent the fire location measured by Aqua MODIS on 28 August 2013.

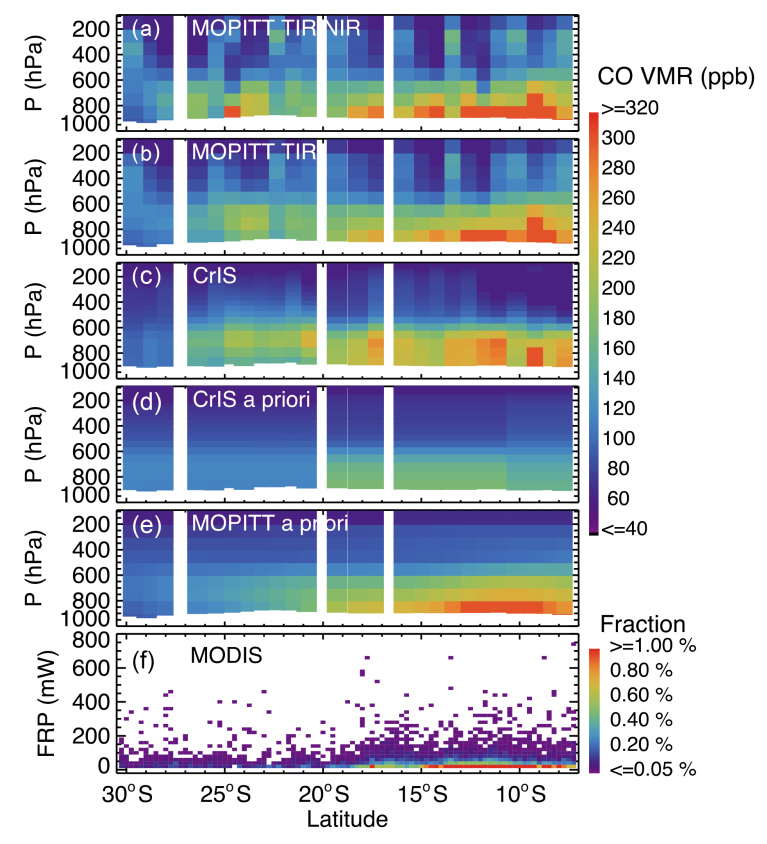

Figure 2. Tropospheric carbon monoxide $(\mathrm{CO})$ volume mixing ratio (parts per billion) profiles measured by Terra MOPITT (version 6.0) on 27 August 2013, Suomi NPP CrIS on 28 August 2013, and fire radiative power (milliwatts) measured by Aqua MODIS. (a) MOPITT joint TIR-NIR CO fields; (b) MOPITT TIR CO fields; (c) CrIS TIR CO fields using a priori profiles used in the Aura TES operational retrievals; (d) a priori CO fields used in CrIS retrievals shown in (c); (e) a priori profiles used in the MOPITT operational retrievals shown in (a) and (b); (f) fire radiative power measured by Aqua MODIS over Africa for 28 August 2013.

\subsection{Carbon monoxide measured from CrIS and MOPITT during an African biomass burning event}

A biomass burning event is observed in Aqua MODIS fire data products (Giglio et al., 2003; Davies et al., 2004), collocated with the CrIS and MOPITT ground tracks, on 27 and 28 August 2013 over Africa (Fig. 1). The CO concen-
Table 3. The differences of carbon monoxide volume mixing ratio in the lower troposphere (surface to $3 \mathrm{~km}(\sim 700 \mathrm{hPa})$ ) between CrIS and MOPITT measurements shown in Fig. $3 \mathrm{a}$.

\begin{tabular}{|c|c|c|c|c|}
\hline \multirow[t]{2}{*}{ Data product } & \multicolumn{2}{|c|}{ Mean } & \multicolumn{2}{|c|}{$\mathrm{rms}$} \\
\hline & $\mathrm{ppb}$ & $\%$ & $\mathrm{ppb}$ & $\%$ \\
\hline CrIS - MOPITT TIR & -6.9 & $-2.9^{*}$ & 22.8 & $9.7^{*}$ \\
\hline $\begin{array}{l}\text { CrIS - MOPITT } \\
\text { Joint TIR-NIR }\end{array}$ & -22.9 & $-8.8^{*}$ & 38.8 & $15.2^{*}$ \\
\hline
\end{tabular}

* It is $100 \times($ CrIS - MOPITT $) /$ MOPITT.

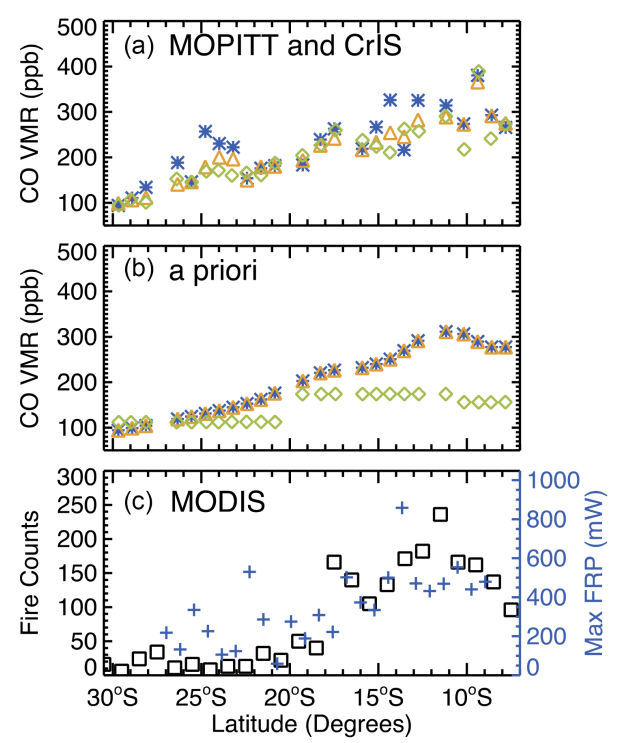

Figure 3. Averaged $\mathrm{CO}$ volume mixing ratio (parts per billion) from the surface to $3 \mathrm{~km}(\sim 700 \mathrm{hPa})$, fire counts, and maximum fire radiative power (milliwatts) measured by Aqua MODIS over Africa for 28 August 2013. (a) MOPITT joint TIR-NIR CO data products (blue stars), MOPITT TIR CO data products (green triangles), and CrIS TIR CO VMR using a priori profiles identical to those used in the Aura TES operational retrievals (golden diamonds); (b) a priori CO VMR used in MOPITT (green/blue) and CrIS (gold) retrievals; (c) fire counts (black squares) and maximum fire radiative power (blue plus) among the Aqua MODIS measurements whose data quality confidences are greater than $70 \%$.

tration in the LMT during this biomass burning event shows a strong latitudinal gradient with local variation, based on the MOPITT data (Fig. 2a). This gradient provides an excellent opportunity to evaluate the performance of CrIS and future CrIS-TROPOMI retrievals (Sect. 3.3). We applied the MUSES algorithm to retrieve CO profiles using real CrIS full-spectral-resolution, single-footprint measurements and then compared the retrieved profiles to the collocated MOPITT retrievals. When running in the retrieval mode that only uses CrIS measurements, the TROPOMI terms in the righthand side of Eqs. (2) and (3) vanish. 
Table 4. Degrees of freedom for MOPITT, CrIS, and TROPOMI carbon monoxide measurements.

\begin{tabular}{llrrr}
\hline Altitude range & Sensor & TIR & NIR & Joint TIR-NIR \\
\hline \multirow{3}{*}{ Surface to top of atmosphere } & MOPITT & 1.44 & 0.51 & 1.88 \\
& CrIS & 1.57 & - & $2.22^{*}$ \\
& TROPOMI & - & 1.32 & 0.77 \\
\hline \multirow{2}{*}{ LMT: surface to $3 \mathrm{~km}(\sim 700 \mathrm{hPa})$} & MOPITT & 0.56 & 0.30 & $0.91^{*}$ \\
& CrIS & 0.62 & - & 1.11 \\
& TROPOMI & - & 0.61 & $1.32^{*}$ \\
$3 \mathrm{~km}(\sim 700 \mathrm{hPa})$ to top of atmosphere & MOPITT & 0.89 & 0.21 & \\
& CrIS & 0.94 & - & \\
& TROPOMI & - & 0.71 & \\
\hline
\end{tabular}

* It is the synergistic CrIS-TROPOMI product.

Table 5. Estimated percentage uncertainty for MOPITT, CrIS, and TROPOMI carbon monoxide measurements.

\begin{tabular}{llrrr}
\hline Altitude range & Sensor & TIR & NIR & Joint TIR-NIR \\
\hline \multirow{3}{*}{ Surface to top of atmosphere } & MOPITT & 8.4 & 9.9 & 8.2 \\
& CrIS & 3.1 & - & $2.9^{*}$ \\
& TROPOMI & - & 3.2 & 14.3 \\
\multirow{2}{*}{ LMT: surface to $3 \mathrm{~km}(\sim 700 \mathrm{hPa})$} & MOPITT & 14.1 & 17.1 & $9.2^{*}$ \\
& CrIS & 13.8 & - & 9.7 \\
& TROPOMI & - & 13.5 & $3.0^{*}$ \\
\hline \multirow{2}{*}{$3 \mathrm{~km}(\sim 700 \mathrm{hPa})$ to top of atmosphere } & MOPITT & 9.5 & 11.3 & - \\
& CrIS & 3.1 & - & 3.2 \\
\hline
\end{tabular}

* It is the synergistic CrIS-TROPOMI product.

The CrIS measurements clearly capture the $\mathrm{CO}$ gradient centered at $10^{\circ} \mathrm{S}$ and diminishing poleward to roughly $20^{\circ} \mathrm{S}$ (Figs. 2c, d and 3a), associated with the biomass burning event detected by the enhanced MODIS radiative fire power (Fig. 1). Table 3 shows that the mean and root mean square (rms, or standard deviation) of the difference between CrIS and MOPITT TIR CO observations in the LMT is $-6.9 \pm 22.8 \mathrm{ppb}$, which is better than the differences between CrIS and MOPITT multispectral observations $(-22.9 \pm 38.8 \mathrm{ppb}$, Table 3$)$. The differences between CrISand MOPITT-observed CO VMR could arise from the following four sources: (1) a priori CO profiles used in the retrievals (Figs. 2d, e and 3b); (2) measurement sensitivity; (3) measurement date/time (MOPITT local time 10:30 on 27 August, CrIS local time 13:30 on 28 August 2013), which could lead to different meteorological conditions; and (4) differences in auxiliary parameters such as surface temperature, temperature profiles, water vapor, and cloud information.

The diurnal variation of MODIS fire radiative power and fire counts for the time period of 27 to 28 August 2013, is weak. The retrievals for the same set of soundings were recomputed using a constant $\mathrm{CO}$ a priori profile, which is $100.0 \mathrm{ppb}$ in the LMT (Fig. S1 in the Supplement) and rep- resentative of clean air conditions. When using common a priori profiles, both MOPITT and CrIS retrievals still show a latitudinal gradient (Figs. S1 and S2) with enhanced CO VMR peaked near $12^{\circ} \mathrm{S}$, similar to the gradient shown in Fig. 3, though the amplitude of CO-enhanced concentration is smaller. Consequently, it indicates that the consistency of measurements from two TIR sensors is insensitive to the choice of a priori. The mean differences between CrIS and MOPITT TIR improved to $2.8 \mathrm{ppb}$ (Table S1 in the Supplement), with the rms (or standard deviation) of the difference changed from 9.7 to $13.9 \%$. Tables 4 and 5 show the measurement characteristics (DOF in Table 4 and uncertainty in Table 5) of the MOPITT and CrIS-TROPOMI. The mean and rms of the differences between CrIS and MOPITT multispectral CO data products are $-23.6 \pm 37.6 \mathrm{ppb}$ (or $-9.7 \pm 16.8 \%$, Table $\mathrm{S} 1$ ), which is greater than the differences between CrIS and MOPITT TIR $(2.8 \pm 24.9 \mathrm{ppb}$ or $1.6 \pm 13.9 \%$, Table S1) and also greater than the estimated measurement uncertainty (CrIS $13.8 \%$; MOPITT joint TIRNIR $14.3 \%$, Table 5). This difference is expected between CrIS and MOPITT multispectral sensitivity as quantified by the averaging kernels, which represent the sensitivity of the $\mathrm{CO}$ retrieval to the true state, as shown in Fig. $4 \mathrm{a}$ and $\mathrm{b}$ for 

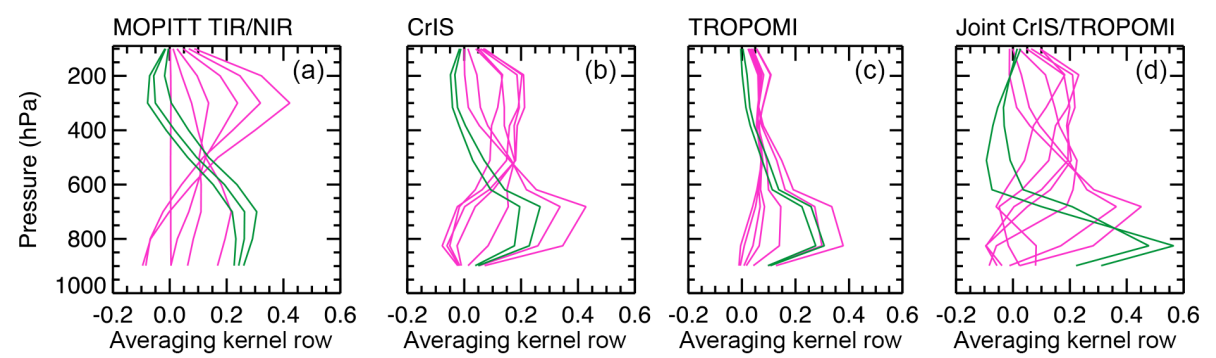

Figure 4. Sample averaging kernels of measurements for the target scene near $22.99^{\circ} \mathrm{E}, 8.65^{\circ} \mathrm{S}$. In all panels, green lines are the averaging kernels from the surface to $3 \mathrm{~km}(\sim 700 \mathrm{hPa})$; magenta lines are the averaging kernels from $3 \mathrm{~km}(\sim 700 \mathrm{hPa})$ to $100 \mathrm{hPa}$. (a) MOPITT joint NIR-TIR measurements; (b) Suomi NPP CrIS TIR measurements; (c) synthetic S5p TROPOMI NIR measurements; (d) synthetic joint CrIS-TROPOMI (TIR-NIR) measurements.
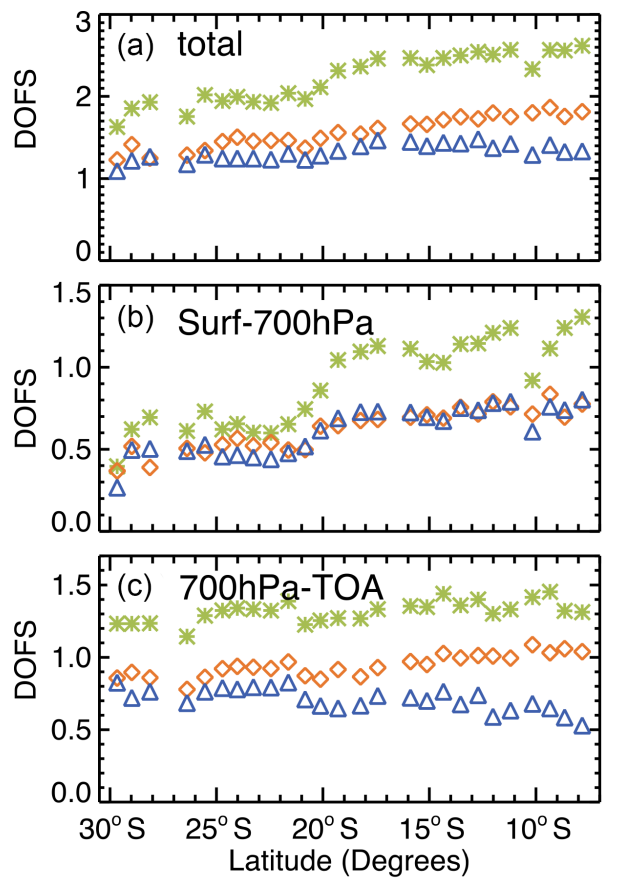

Figure 5. Degrees of freedom for $\mathrm{CO}$ measurements from CrIS, along with the synthetic TROPOMI alone and joint CrIS and TROPOMI measurements over the biomass burning region. Green stars are the DOF for joint TROPOMI and CrIS; gold diamonds are for the DOF for CrIS; and blue triangles are for DOF from TROPOMI measurements.

CrIS and MOPITT, respectively. The higher-amplitude averaging kernels for MOPITT multispectral observations in Fig. $4 \mathrm{~b}$ quantify the enhanced near-surface sensitivity.

\subsection{Characteristics of joint TROPOMI and CrIS CO profile retrievals}

To access the characteristics of improved tropospheric $\mathrm{CO}$ profiling when combining TIR-NIR observations, we computed the averaging kernels, degrees of freedom for signal (DOF, the trace of averaging kernels), and error covariance matrix for both synergistic and each-instrument-alone observations. We used the CrIS viewing geometry for the simulation of TROPOMI measurements (described in Sect. 3.1) since the tandem orbit of Suomi NPP and TROPOMI is very similar.

Figures 4-6 and Tables 4-5 show the retrieval diagnostics. We find that the CO profiles generated from joint CrISTROPOMI measurements show improvements on the vertical resolution (Fig. 4d) and sensitivity (mean total DOF of 2.22, Table 4), in comparison to the MOPITT joint TIRNIR measurements (Figs. 4a, 6a; Table 4; mean total DOF of 1.88), while the estimated total uncertainty (magenta lines in Fig. $6 \mathrm{~b}$ and $\mathrm{c}$ ) is smaller than that of MOPITT joint TIR-NIR measurements. The synergistic CrIS-TROPOMI observations clearly distinguish the LMT (green lines in Fig. 4d) and middle troposphere (magenta lines in Fig. 4d). The synergistic CrIS-TROPOMI measurements show significant improvements on the sensitivity in comparisons to individual measurements from both CrIS and TROPOMI missions (Figs. 4b, c and 5; Table 4). The latitudinal gradient of biomass burning intensity (Figs. 2f, 3c, fire counts 0 250; max fire radiative power $0-800 \mathrm{~mW}$ ), CO concentration (Fig. 3a, 100-400 ppb), and DOF (Fig. 5; CrIS 1-1.7; TROPOMI 1-1.5) show a similar pattern across the transect. The synergistic CrIS-TROPOMI, however, has higher DOF, generally above 2 (Fig. 5a), because of its higher LMT sensitivity (Table 4, DOF of 0.9 for joint vs. 0.6 for CrIS and TROPOMI alone). And the sensitivity of MOPITT TIR and CrIS measurements for LMT are approximately identical $(0.56$ vs. 0.62$)$. The estimated sensitivity of joint CrISTROPOMI measurements show improvements in comparisons to MOPITT synergistic TIR-NIR observations, possibly a consequence of TROPOMI's "staring" viewing mode, which does not have the issue of geophysical radiance error found by Deeter et al. (2011) for the MOPITT NIR sensor, which is a "dragging" instrument. It is worth noting that the minimum spectral SNR of TROPOMI measurements was used in synthetic TROPOMI-alone and joint CrIS-TROPOMI measurements; the actual performances of 

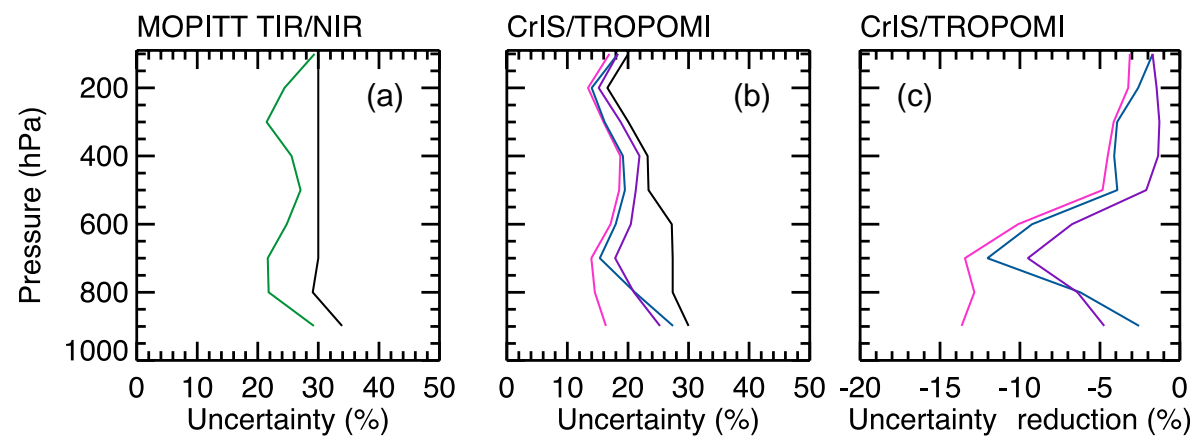

Figure 6. Uncertainties of the CO volume mixing ratio (VMR) profiles near $22.99^{\circ} \mathrm{E}, 8.65^{\circ} \mathrm{S}$ on 28 August 2013. (a) Uncertainty of the joint MOPITT multispectral CO products (green line) and a priori profile (black line). (b) Uncertainty of CrIS actual CO measurements (blue line), synthetic TROPOMI (purple line), and joint CrIS-TROPOMI (magenta line) CO measurements. Black line is the uncertainty of a priori profile used in the retrievals. (c) The reduction on the uncertainty with respect to the uncertainty of a priori profile.

joint CrIS-TROPOMI could be even better than that shown in Figs. 4-6.

The total error (or uncertainty) consists of two terms (Eq. 5): the first term represents the smoothing error, and the second term is the measurement error. By incorporating radiances measured by two nadir-viewing instruments (Eq. 3), the error characteristics of joint CrIS-TROPOMI tropospheric $\mathrm{CO}$ estimates can be substantially improved, in comparison with joint CrIS-TROPOMI and each instrument alone. Particularly, in the altitude range from the surface to $3 \mathrm{~km}(\sim 700 \mathrm{hPa})$, we have seen the total uncertainty reduced from $30 \%$ (using measurements from each instrument alone) to $15 \%$ (joint TIR-NIR). This increased sensitivity and decrease in uncertainty are critical for evaluating the role of tropical fires (or pyro-convection) in the $\mathrm{CO}$ distribution (Fromm et al., 2005, 2006).

\section{Conclusions}

Based upon the MUSES synergistic retrieval algorithm, the combined CrIS-TROPOMI observations can extend and improve on the EOS-Terra MOPITT multispectral carbon monoxide profile data products with higher vertical resolution and accuracy compared to any single nadir-viewing platform and over 2.5 times higher spatial sampling than MOPITT.

The MUSES algorithm has been applied to retrieve carbon monoxide volume mixing ratio profiles using full-spectralresolution, single-footprint CrIS measurements over Africa on 28 August 2013. The agreement of retrieved carbon monoxide volume mixing ratio in the lowermost troposphere (surface to $3 \mathrm{~km} ; \sim 700 \mathrm{hPa}$ ) between CrIS and MOPITT TIR data products on 27 August 2013 is $-6.9 \pm 22.8$ ppb when using different a priori profiles in retrievals and $2.8 \pm 24.9 \mathrm{ppb}$ when using common a priori in retrievals.

The simulated synergistic retrievals of CrIS-TROPOMI yield 0.9 degrees of freedom for CO signals in the LMT and
1.3 above the LMT, distinguishing signals from the LMT and that above the LMT in the troposphere, similar to that of MOPITT multispectral observation (DOF 0.8 in the LMT, and 1.1 above the LMT). In addition to increased sensitivity, the joint retrievals reduce measurement uncertainty, especially in the LMT: about $15 \%$ error reduction in the altitude range from the surface to $3 \mathrm{~km}(\sim 700 \mathrm{hPa})$. The potentials of synergistic CrIS-TROPOMI observations will be fully exploited using the MUSES algorithm when TROPOMI Level-1B spectral radiances become available. The validation of $\mathrm{CO}$ retrievals using aircraft in situ profiles will be accomplished in the near future.

By achieving information content that rivals the EOSTerra MOPITT measurements, synergistic CrIS-TROPOMI $\mathrm{CO}$ observations not only demonstrably enhance the scientific value of S5p TROPOMI and Suomi NPP; they also extend the climate and tropospheric records needed to continue NASA EOS science. Furthermore, the broad coverage of Suomi NPP will provide global CO (a key tracer gas in the diagnostics of transport and chemical reaction processes in the atmosphere) that complements the NASA Decadal Survey Geostationary Coastal and Air Pollution Events (GEOCAPE) sounder (Fishman et al., 2012; http://geo-cape.larc. nasa.gov/). GEO-CAPE is envisaged as a member of the Committee on Earth Observing Systems (CEOS) air quality constellation, which includes the Korean GEMS (Bak et al., 2013), ESA Sentinel-4 (Ingmann et al., 2012; www.ceos. org/acc?), and possibly Canadian PCW missions (Nassar et al., 2014; http://www.asc-csa.gc.ca/eng/satellites/pcw/). The joint CrIS-TROPOMI retrieval algorithm can also be applied to the future joint Sentinel-5 UVNS-IASI-NG observations from MetOp Second Generation satellites, which could provide joint NIR-TIR CO measurements in the time period of 2022-2045 (Veefkind et al., 2012; Crevoisier et al., 2014). The joint CrIS-TROPOMI CO profiles will enable the quantification of transport and transformation of atmospheric composition in the domains unobserved by this constellation. This combination of low-Earth-orbiting and geostationary 
space sounders would provide an unprecedented atmospheric composition observing system needed to address long-term scientific questions in climate, air quality, and atmospheric chemistry.

\section{The Supplement related to this article is available online at doi:10.5194/amt-9-2567-2016-supplement.}

Acknowledgements. The authors thank David Crisp, Annmarie Eldering, Michael R. Gunson, Susan S. Kulawik, Karen Cady-Pereira, Vivienne H. Payne, Bradley R. Pierce, and Stanley P. Sander for many helpful discussions. Support from the NASA ROSE-2013 Atmospheric Composition: AURA Science Team program (grant number: NNN13D455T) is gratefully acknowledged. Part of the research was carried out at the Jet Propulsion Laboratory, California Institute of Technology, under a contract with the National Aeronautics and Space Administration. We than the editor, I. Moradi for his excellent work.

Edited by: I. Moradi

\section{References}

Allen, N. D. C., Bernath, P. F., Boone, C. D., Chipperfield, M. P., Fu, D., Manney, G. L., Oram, D. E., Toon, G. C., and Weisenstein, D. K.: Global carbon tetrachloride distributions obtained from the Atmospheric Chemistry Experiment (ACE), Atmos. Chem. Phys., 9, 7449-7459, doi:10.5194/acp-9-7449-2009, 2009.

Aumann, H., Chahine, M. T., Gautier, C., Goldberg, M. D, Kalnay, E., McMillin, L. M., Revercomb, H., Rosenkranz, P. W., Smith, W. L., Staelin, D. H., Strow, L. L., and Susskind J.: AIRS/AMSU/HSB on the Aqua mission: Design, science objectives, data products, and processing systems, IEEE T. Geosci. Remote Sensing, 41, 253-264, 2003.

Bak, J., Kim, J. H., Liu, X., Chance, K., and Kim, J.: Evaluation of ozone profile and tropospheric ozone retrievals from GEMS and OMI spectra, Atmos. Meas. Tech., 6, 239-249, doi:10.5194/amt6-239-2013, 2013.

Baker, N.: Joint Polar Satellite System (JPSS) VIIRS Cloud Cover/Layers Algorithm Theoretical Basis Document (ATBD), NASA Goddard Space Flight Center Technical Report, 2011a.

Baker, N.: Joint Polar Satellite System (JPSS) VIIRS Cloud Effective Particle Size and Cloud Optical Thickness Algorithm Theoretical Basis Document (ATBD), NASA Goddard Space Flight Center Technical Report, 2011b.

Baker, N.: Joint Polar Satellite System (JPSS) Cloud Top Algorithm Theoretical Basis Document (ATBD), NASA Goddard Space Flight Center Technical Report, 2012.

Bernath, P. F., McElroy, C. T., Abrams, M. C., Boone, C. D, Butler, M., Camy-Peyret, C., Carleer, M., Clerbaux, C., Coheur, P.-F., Colin, R., DeCola, P., DeMazière, M., Drummond, J. R., Dufour, D., Evans, W. F. J., Fast, H., Fussen, D., Gilbert, K., Jennings, D. E., Llewellyn, E. J., Lowe, R. P., Mahieu, E., McConnell, J. C.,
McHugh, M., McLeod, S. D., Michaud, R., Midwinter, C., Nassar, R., Nichitiu, F., Nowlan, C., Rinsland, C. P., Rochon, Y. J., Rowlands, N., Semeniuk, K., Simon, P., Skelton, R., Sloan, J. J., Soucy, M.-A., Strong, K., Tremblay, P., Turnbull, D., Walker, K. A., Walkty, I., Wardle, D. A., Wehrle, V., Zander, R., and Zou, J.: Atmospheric Chemistry Experiment (ACE): Mission overview, Geophys. Res. Lett., 32, L15S01, doi:10.1029/2005GL022386, 2005.

Boone, C. D., Nassar, R., Walker, K. A., Rochon, Y., McLeod, S. D., Rinsland, C. P., and Bernath, P. F.: Retrievals for the atmospheric chemistry experiment Fourier-transform spectrometer, Appl. Optics, 44, 7218-7231, 2005.

Boesch, H., Brown, L., Castano, R., Christi, M., Connor, B., Crisp, D., Eldering, A., Fisher, B., Frankenberg, C., Gunson, M., Granat, R., McDuffie, J., Miller, C., Natraj, V., O’Brien, D., O’Dell, C., Osterman, G., Oyafuso, F., Payne, V., Polonski, I., Smyth, M., Spurr, R., Thompson, D., and Toon, G.: Orbiting Carbon Observatory-2 (OCO2) Level 2 full physics retrieval algorithm theoretical basis, version 2.0 revision 2, 30 March 2015, data releases 6 and 6R, available at: http://disc.sci.gsfc.nasa.gov/OCO-2/ documentation/oco-2-v6/OCO2_L2_ATBD.V6.pdf, 2015.

Bowman, K. W., Rodgers, C. D., Kulawik, S. S., Worden, J., Sarkissian, E., Osterman, G., Steck, T., Lou, M., Eldering, A., Shephard, M., Worden, H., Lampel, M., Clough, S., Brown, P., Rinsland, C., Gunson, M., and Beer, R.: Tropospheric Emission Spectrometer: Retrieval Method and Error Analysis, IEEE T. Geosci. Remote Sensing, 44, 1297-1307, 2006.

Brasseur, G. P., Hauglustaine, D. A., Walters, S., Rasch, P. J., Muller, J. F., Granier, C., and Tie, X. X.: MOZART, a global chemical transport model for ozone and related chemical tracers 1. Model description, J. Geophys. Res., 103, 28265-28289, 1998.

Buchard, V., da Silva, A. M., Colarco, P. R., Darmenov, A., Randles, C. A., Govindaraju, R., Torres, O., Campbell, J., and Spurr, R.: Using the OMI aerosol index and absorption aerosol optical depth to evaluate the NASA MERRA Aerosol Reanalysis, Atmos. Chem. Phys., 15, 5743-5760, doi:10.5194/acp-15-57432015, 2015.

Clerbaux, C., Edwards, D. P., Deeter, M., Emmons, L., Lamarque, J.-F., Tie, X. X., Massie, S. T., and Gille, J.: Carbon monoxide pollution from cities and urban areas observed by the Terra/MOPITT mission, Geophys. Res. Lett., 35, L03817, doi:10.1029/2007GL032300, 2008a.

Clerbaux, C., George, M., Turquety, S., Walker, K. A., Barret, B., Bernath, P., Boone, C., Borsdorff, T., Cammas, J. P., Catoire, V., Coffey, M., Coheur, P.-F., Deeter, M., De Mazière, M., Drummond, J., Duchatelet, P., Dupuy, E., de Zafra, R., Eddounia, F., Edwards, D. P., Emmons, L., Funke, B., Gille, J., Griffith, D. W. T., Hannigan, J., Hase, F., Höpfner, M., Jones, N., Kagawa, A., Kasai, Y., Kramer, I., Le Flochmoën, E., Livesey, N. J., López-Puertas, M., Luo, M., Mahieu, E., Murtagh, D., Nédélec, P., Pazmino, A., Pumphrey, H., Ricaud, P., Rinsland, C. P., Robert, C., Schneider, M., Senten, C., Stiller, G., Strandberg, A., Strong, K., Sussmann, R., Thouret, V., Urban, J., and Wiacek, A.: CO measurements from the ACE-FTS satellite instrument: data analysis and validation using ground-based, airborne and spaceborne observations, Atmos. Chem. Phys., 8, 2569-2594, doi:10.5194/acp-8-2569-2008, 2008b. 
Clough, S. A., Shephard, M. W., Worden, J., Brown, P. D., Worden, H. M., Luo, M., Rodgers, C. D., Rinsland, C. P., Goldman, A., Brown, L., Kulawik, S. S., Eldering, A., Lampel, M. C., Osterman, G., Beer, R., Bowman, K., Cady-Pereira, K. E., and Mlawer, E. J.: Forward Model and Jacobians for Tropospheric Emission Spectrometer Retrievals, IEEE T. Geosci. Remote Sens., 44, 1308-1323, 2006.

Crevoisier, C., Clerbaux, C., Guidard, V., Phulpin, T., Armante, R., Barret, B., Camy-Peyret, C., Chaboureau, J.-P., Coheur, P.F., Crépeau, L., Dufour, G., Labonnote, L., Lavanant, L., HadjiLazaro, J., Herbin, H., Jacquinet-Husson, N., Payan, S., Péquignot, E., Pierangelo, C., Sellitto, P., and Stubenrauch, C.: Towards IASI-New Generation (IASI-NG): impact of improved spectral resolution and radiometric noise on the retrieval of thermodynamic, chemistry and climate variables, Atmos. Meas. Tech., 7, 4367-4385, doi:10.5194/amt-7-4367-2014, 2014.

Cuesta, J., Eremenko, M., Liu, X., Dufour, G., Cai, Z., Höpfner, M., von Clarmann, T., Sellitto, P., Foret, G., Gaubert, B., Beekmann, M., Orphal, J., Chance, K., Spurr, R., and Flaud, J.-M.: Satellite observation of lowermost tropospheric ozone by multispectral synergism of IASI thermal infrared and GOME-2 ultraviolet measurements over Europe, Atmos. Chem. Phys., 13, 9675-9693, doi:10.5194/acp-13-9675-2013, 2013.

Davies, D., Kumar, S., and Descloitres, J.: Global fire monitoring using MODIS near-real-time satellite data, GIM International, 18, 41-43, 2004.

Deeter, M. N., Worden, H. M., Gille, J. C., Edwards, D. P., Mao, D., and Drummond, J. R.: MOPITT multispectral CO retrievals: Origins and effects of geophysical radiance errors, J. Geophys. Res., 116, D15303, doi:10.1029/2011JD015703, 2011.

Deeter, M. N., Martínez-Alonso, S., Edwards, D. P., Emmons, L. K., Gille, J. C., Worden, H. M., Pittman, J. V., Daube, B. C., and Wofsy, S. C.: Validation of MOPITT Version 5 thermalinfrared, near-infrared, and multispectral carbon monoxide profile retrievals for 2000-2011, J. Geophys. Res., 118, 6710-6725, 2013

Deeter, M. N., Martínez-Alonso, S., Edwards, D. P., Emmons, L. K., Gille, J. C., Worden, H. M., Sweeney, C., Pittman, J. V., Daube, B. C., and Wofsy, S. C.: The MOPITT Version 6 product: algorithm enhancements and validation, Atmos. Meas. Tech., 7, 3623-3632, doi:10.5194/amt-7-3623-2014, 2014.

de Laat, A. T. J., Gloudermans, A. M. S., Aben, I., Krol, M., Meirink, J. F., van der Werf, G. R., and Schrijver, H.: Scanning Imaging Absorption Spectrometer for Atmospheric Chartography carbon monoxide total columns: Statistical evaluation and comparison with chemistry transport model results, J. Geophys. Res., 112, D12310, doi:10.1029/2006JD008256, 2007.

Drummond, J. R.: Measurements of Pollution in the Troposphere (MOPITT), in: The Use of EOS for Studies of Atmospheric Physics, edited by: Gille, J. C. and Visconti, G., North-Holland, Amsterdam, 77-101, 1992.

Edwards, D. P., Emmons, L. K., Gille, J. C., Chu, A., Attié, J.-L., Giglio, L., Wood, S. W., Haywood, J., Deeter, M. N., Massie, S. T., Ziskin, D. C., and Drummond, J. R.: Satellite-observed pollution from Southern Hemisphere biomass burning, J. Geophys. Res., 111, D14312, doi:10.1029/2005JD006655, 2006.

Eldering, A., Kulawik, S. S., Worden, J., Bowman, K., and Osterman, G.: Implementation of cloud retrievals for TES atmospheric retrievals: 2 . Characterization of cloud top pressure and effective optical depth retrievals, J. Geophys. Res., 113, D16S37, doi:10.1029/2007JD008858, 2008.

Emmons, L. K., Pfister, G. G., Edwards, D. P., Gille, J. C., Sachse, G., Blake, D., Wofsy, S., Gerbig, C., Matross, D., and Nédélec, P.: Measurements of pollution in the troposphere (MOPITT) validation exercises during summer 2004 field campaigns over North America, J. Geophys. Res., 112, D12S02, doi:10.5194/acp-91795-2009, 2007.

Emmons, L. K., Edwards, D. P., Deeter, M. N., Gille, J. C., Campos, T., Nédélec, P., Novelli, P., and Sachse, G.: Measurements of Pollution In The Troposphere (MOPITT) validation through 2006, Atmos. Chem. Phys., 9, 1795-1803, doi:10.5194/acp-91795-2009, 2009.

Fishman, J., Iraci, L. T., Al-Saadi, J., Chance, K., Chavez, F., Chin, M., Coble, P., Davis, C., DiGiacomo, P. M., Edwards, D., Eldering, A., Goes, J., Herman, J., Hu, C., Jacob, D. J., Jordan, C., Kawa, S. R., Key, R., Liu, X., Lohrenz, S., Mannino, A., Natraj, V., Neil, D., Neu, J., Newchurch, M., Pickering, K., Salisbury, J., Sosik, H., Subramaniam, A., Tzortziou, M., Wang, J., and Wang, M.: The United States' Next Generation of Atmospheric Composition and Coastal Ecosystem Measurements: NASA's Geostationary Coastal and Air Pollution Events (GEO-CAPE) Mission, B. Am. Meteor. Soc., 93, 1547-1566, 2012.

Fortems-Cheiney, A., Chevallier, F., Pison, I., Bousquet, P., Szopa, S., Deeter, M. N., and Clerbaux, C.: Ten years of $\mathrm{CO}$ emissions as seen from Measurements of Pollution in the Troposphere (MOPITT), J. Geophys. Res., 116, D05304, doi:10.1029/2010JD014416, 2011.

Fromm, M., Bevilacqua, R., Servranckx, R., Rosen, J., Thayer, J. P., Herman, J., and Larko, D.: Pyro-cumulonimbus injection of smoke to the stratosphere: Observations and impact of a super blowup in northwestern Canada on 3-4 August 1998, J. Geophys. Res., 110, D08205, doi:10.1029/2004JD005350, 2005.

Fromm, M., Tupper, A., Rosenfeld, D., Servranckx, R., and McRae, R.: Violent pyro-convective storm devastates Australia's capital and pollutes the stratosphere, Geophys. Res. Lett., 33, L05815, doi:10.1029/2005GL025161, 2006.

Fu, D., Boone, C. D., Bernath, P. F., Walker, K. A., Nassar, R., Manney, G. L., and McLeod, S. D.: Global phosgene observations from the Atmospheric Chemistry Experiment (ACE) mission, Geophys. Res. Lett., 34, L17815, doi:10.1029/2007GL029942, 2007.

Fu, D., Boone, C. D., Bernath, P. F., Weisenstein, D. K., Rinsland, C. P., Manney, G. L., and Walker, K. A.: First global observations of atmospheric COClF from the Atmospheric Chemistry Experiment mission, J. Quant. Spectrosc. Rad. Trans., 110, 974-985, 2009.

Fu, D., Worden, J. R., Liu, X., Kulawik, S. S., Bowman, K. W., and Natraj, V.: Characterization of ozone profiles derived from Aura TES and OMI radiances, Atmos. Chem. Phys., 13, 3445-3462, doi:10.5194/acp-13-3445-2013, 2013.

Gambacorta, A., Barnet, C., Wolf, W., King, T., Maddy, E., Strow, L., Xiong, X., Nalli, N., and Goldberg, M.: An Experiment Using high spectral resolution CrIS measurements for atmospheric trace gases: carbon monoxide retrieval impact study, IEEE Geosci. Remote Sens. Lett., 11, 1639-1643, 2014.

George, M., Clerbaux, C., Hurtmans, D., Turquety, S., Coheur, P.F., Pommier, M., Hadji-Lazaro, J., Edwards, D. P., Worden, H., Luo, M., Rinsland, C., and McMillan, W.: Carbon monoxide dis- 
tributions from the IASI/METOP mission: evaluation with other space-borne remote sensors, Atmos. Chem. Phys., 9, 8317-8330, doi:10.5194/acp-9-8317-2009, 2009.

Giglio, L., Descloitres, J., Justice, C. O., and Kaufman, Y. J.: An enhanced contextual fire detection algorithm for MODIS, Remote Sens. Environ., 87, 273-282, 2003.

Han, Y., Revercomb, H., Cromp, M., Gu, D., Johnson, D., Mooney, D., Scott, D., Strow, L., Bingham, G., Borg, L., Chen, C., DeSlover, D., Esplin, M., Hagan, D., Jin, X., Knuteson, R., Motteler, H., Predina, J., Suwinski, L., Taylor, J., Tobin, D., Tremblay, D., Wang, C., Wang, L., Wang, L., and Zavyalov, V.: Suomi NPP CrIS measurements, sensor data record algorithm, calibration and validation activities, and record data quality, J. Geophys. Res. Atmos., 118, 12734-12748, 2013.

Han, Y., Chen, Y., Xiong, X., and Jin, X.: S-NPP CrIS full spectral resolution SDR processing and data quality assessment, 95th AMS Annual Meeting, Phoenix, Arizona, January 2015.

Heald, C. L., Jacob, D. J., Fiore, A. M., Emmons, L. K., Gille, J. C., Deeter, M. N., Warner, J., Edwards, D. P., Crawford, J. H., Hamlin, A. J., Sachse, G. W., Browell, E. V., Avery, M. A., Vay, S. A., Westberg, D. J., Blake, D. R., Singh, H. B., Sandholm, S. T., Talbot, R. W., and Fuelberg, H. E.: Asian outflow and transPacific transport of carbon monoxide and ozone pollution: An integrated satellite, aircraft, and model perspective, J. Geophys. Res., 108, 4804-4820, 2003.

Hook, S., Friedl, M., Sulla-Menashe, D., Gray, J., Schaaf, C., Wang, Z., Miura, T., Huete, A., Maslanik, J., Tschudi, M., Baldwin, D., Key, J. R., Wang, X., Liu, Y., Riggs, G., Hall, D., Ellicott, E., Giglio, L., Schroeder, W., Csiszar, I., Lyapustin, A., Vermote, E., Wang, Y., Myneni, R., Wolfe, R., Foster, J., Masuoka, E. J., Devadiga, S., and Davidson, C.: An Evaluation of the SuomiNPP Visible Infrared Imaging Radiometer Suite (VIIRS) and the Associated Environmental Data Records for Land Science after Early Evaluation on On-Orbit Performance, NASA Goddard Space Flight Center Technical Report, 2012.

Ingmann, P., Veihelmann, B., Langen, J., Lamarre, D., Stark, H., Bazalgette, G., and Lacoste, C.: Requirements for the GMES Atmosphere Service and ESA's implementation concept: Sentinels4/-5 and -5p, Remote Sens. Environ., 120, 58-69, 2012.

Kalnay, E., Kanamitsu, M., Kistler, R., Collins, W., Deaven, D., Gandin, L., Iredell, M., Saha, S., White, G., Woollen, J., Zhu, Y., Chelliah, M., Ebisuzaki, W., Higgins, W., Janowiak, J., Mo, K. C., Ropelewski, C., Wang, J., Leetmaa, A., Reynolds, R., Jenne, R., and Joseph, D.: The NCEP/NCAR 40-year reanalysis project, B. Am. Meteor. Soc., 77, 437-471, 1996.

Kar, J., Deeter, M. N., Fishman, J., Liu, Z., Omar, A., Creilson, J. K., Trepte, C. R., Vaughan, M. A., and Winker, D. M.: Wintertime pollution over the Eastern Indo-Gangetic Plains as observed from MOPITT, CALIPSO and tropospheric ozone residual data, Atmos. Chem. Phys., 10, 12273-12283, doi:10.5194/acp-1012273-2010, 2010.

Kopacz, M., Jacob, D. J., Henze, D. K., Heald, C. L., Streets, D. G., and Zhang, Q.: Comparison of adjoint and analytical Bayesian inversion methods for constraining Asian sources of carbon monoxide using satellite (MOPITT) measurements of CO columns, J. Geophys. Res., 114, D04305, doi:10.1029/2007JD009264, 2009.

Kulawik, S. S., Worden, J., Eldering, A., Bowman, K., Gunson, M., Osterman, G. B., Zhang, L., Clough, S., Shephard, M. W., and
Beer, R.: Implementation of cloud retrievals for Tropospheric Emission Spectrometer (TES) atmospheric retrievals: part 1. Description and characterization of errors on trace gas retrievals, J. Geophys. Res., 111, D24204, doi:10.1029/2005JD006733, 2006. Landgraf, J. and Hasekamp, O. P.: Retrieval of tropospheric ozone: The synergistic use of thermal infrared emission and ultraviolet reflectivity measurements from space, J. Geophys. Res., 112, D08310, doi:10.1029/2006JD008097, 2007.

Luo, M., Read, W., Kulawik, S., Worden, J., Livesey, N., Bowman, K., and Herman, R.: Carbon monoxide (CO) vertical profiles derived from joined TES and MLS measurements, J. Geophys. Res., 118, 1-13, 2013.

McMillan, W. W., Barnet, C., Strow, L., Chahine, M. T., McCourt, M. L., Warner, J. X., Novelli, P. C., Korontzi, S., Maddy, E. S., and Datta, S.: Daily global maps of carbon monoxide from NASA's Atmospheric Infrared Sounder, Geophys. Res. Lett., 32, L11801, 1-4, 2005.

Nassar, R., Sioris, C. E., Jones, D. B. A., and McConnell, J. C.: Satellite observations of $\mathrm{CO}_{2}$ from a highly elliptical orbit for studies of the Arctic and boreal carbon cycle, J. Geophys. Res. Atmos., 119, 2654-2673, 2014.

Pagano, T. S., Aumann, H. H., Hagan, D. E., and Overoye, K.: Prelaunch and in-flight radiometric calibration of the Atmospheric Infrared Sounder (AIRS), IEEE T. Geosci. Remote Sens., 41, 265-273, 2003.

Park, M., Randel, W. J., Kinnison, D. E., Garcia, R. R., and Choi, W.: Seasonal variation of methane, water vapor, and nitrogen oxides near the tropopause: Satellite observations and model simulations, J. Geophys. Res., Atmos., 109, D03302, doi:10.1029/2003JD003706, 2004.

Platnick, S, Ackerman, S. A., Baum, B. A., Heidinger, A. K., Holz, R. E., King, M. D., Menzel, W. P., Nasiri, S., Weisz, E., and Yang, P.: Assessment of IDPS VIIRS Cloud Products and Recommendations for EOS-ERA Cloud Climate Data Record Continuity, NASA Goddard Space Flight Center Technical Report, 2013.

Rienecker, M., Suarez, M. J., Todling, R., Bacmeister, J., Takacs, L., Liu, H.-C., Gu, W., Sienkiewicz, M., Koster, R. D., Gelaro, R., Stajner, I., and Nielsen, J. E.: The GEOS-5 data assimilation system-documentation of versions 5.0.1, 5.1.0, and 5.2.0., technical report series on global modeling and data assimilation, 104606, 27, 2008.

Rienecker, M. M., Suarez, M. J., Gelaro, R., Todling, R., Bacmeister, J., Liu, E., Bosilovich, M. G., Schubert, S. D., Takacs, L., Kim, G.-K., Bloom, S., Chen, J., Collins, D., Conaty, A., da Silva, A., Gu, W., Joiner, J., Koster, R. D., Lucchesi, R., Molod, A., Owens, T., Pawson, S., Pegion, P., Redder, C. R., Reichle, R., Robertson, F. R., Ruddick, A. G., Sienkiewicz, M., and Woollen, J.: MERRA: NASA's Modern-Era Retrospective Analysis for Research and Applications, J. Climate, 24, 3624-3648, 2011.

Rinsland, C. P., Luo, M., Logan, J. A., Beer, R., Worden, H., Kulawik, S. S., Rider, D., Osterman, G., Gunson, M., Eldering, A., Goldman, A., Shephard, M., Clough, S. A., Rodgers, C., Lampel, M., and Chiou, L.: Nadir measurements of carbon monoxide distributions by the Tropospheric Emission Spectrometer instrument onboard the Aura Spacecraft: Overview of analysis approach and examples of initial results, Geophys. Res. Lett., 33, L22806, doi:10.1029/2006GL027000, 2006.

Rodgers, C. D.: Inverse methods for atmospheric sounding: Theory and practice, Word Scientific Publishing, Singapore, 2000. 
Seemann, S. W., Borbas, E. E., Knuteson, R. O., Stephenson, G. R., and Huang, H.-L.: Development of a global infrared land surface emissivity database for application to clear sky sounding retrievals from multispectral satellite radiance measurements, J. Appl. Meteor. Climatol., 47, 108-123, 2008.

Shindell, D. T., Faluvegi, G., Stevenson, D. S., Krol, M. C., Emmons, L. K., Lamarque, J.-F., Pétron, G., Dentener, F. J., Ellingsen, K., Schultz, M. G., Wild, O., Amann, M., Atherton, C. S., Bergmann, D. J., Bey, I., Butler, T., Cofala, J., Collins, W. J., Derwent, R. G., Doherty, R. M., Drevet, J., Eskes, H. J., Fiore, A. M., Gauss, M., Hauglustaine, D. A., Horowitz, L. W., Isaksen, I. S. A., Lawrence, M. G., Montanaro, V., Müller, J.-F., Pitari, G., Prather, M. J., Pyle, J. A., Rast, S., Rodriguez, J. M., Sanderson, M. G., Savage, N. H., Strahan, S. E., Sudo, K., Szopa, S., Unger, N., van Noije, T. P. C., and Zeng, G.: Multimodel simulations of carbon monoxide: Comparison with observations and projected near-future changes, J. Geophys. Res., 111, D19306, doi:10.1029/2006JD007100, 2006.

Silva, S. J., Arellano, A. F., and Worden, H. M.: Toward anthropogenic combustion emission constraints from space-based analysis of urban $\mathrm{CO}_{2} / \mathrm{CO}$ sensitivity, Geophys. Res. Lett., 40, 49714976, 2013.

Spurr, R. J. D.: VLIDORT: A linearized pseudo-spherical vector discrete ordinate radiative transfer code for forward model and retrieval studies in multilayer multiple scattering media, J. Quant. Spectrosc. Ra., 102, 316-342, 2006.

Spurr, R. J. D., de Haan, J., van Oss, R., and Vasilkov, A.: Discrete Ordinate Theory in a Stratified Medium with First Order Rotational Raman Scattering; a General Quasi-Analytic Solution, J. Quant. Spectrosc. Ra., 109, 404-425, 2008.

Strow, L., Blackwell, W., Fishbein, E., Lambrigtsen, B., and Revercomb, H.: NPP Sounding Group Evaluation Report, NASA Goddard Space Flight Center Technical Report, 2013a.

Strow, L. L., Motteler, H., Tobin, D., Revercomb, H., Hannon, S., Buijs, H., Predina, J., Suwinski, L., and Glumb, R.: Spectral calibration and validation of the Cross-track Infrared Sounder on the Suomi NPP satellite, J. Geophys. Res. Atmos., 118, 1248612496, 2013b.

Tobin, D., Revercomb, H., Knuteson, R., Taylor, J., Best, F., Borg, L., DeSlover, D., Martin, G., Buijs, H., Esplin, M., Glumb, R., Han, Y., Mooney, D., Predina, J., Strow, L., Suwinski, L., and Wang, L.: Suomi-NPP CrIS radiometric calibration uncertainty, J. Geophys. Res. Atmos., 118, 10589-10600, 2013.
Veefkind, J. P., Aben, I., McMullan, K., Försterd, H., de Vries, J., Otter, G., Claas, J., Eskes, H. J., de Haan, J. F., Kleipool, Q., van Weele, M., Hasekamp, O., Hoogeveen, R., Landgraf, J., Snel, R., Tol, P., Ingmann, P., Voors, R., Kruizinga, B., Vink, R., Visser, H., and Levelt, P. F.: TROPOMI on the ESA Sentinel-5 Precursor: A GMES mission for global observations of the atmospheric composition for climate, air quality and ozone layer applications, Remote Sens. Environ., 120, 70-83, 2012.

Wang, L., Tremblay, D. A., Han, Y., Esplin, M., Hagan, D. E., Predina, J., Suwinski, L., Jin, X., and Chen, Y.: Geolocation assessment for CrIS sensor data records, J. Geophys. Res. Atmos., 118, 12690-12704, 2013.

Warner, J., Comer, M. M., Barnet, C. D., McMillan, W. W., Wolf, W., Maddy, E., and Sachse, G.: A comparison of satellite tropospheric carbon monoxide measurements from AIRS and MOPITT during INTEX-A, J. Geophys. Res., 112, D12S17, doi:10.1029/2006JD007925, 2007.

Worden, H. M., Deeter, M. N., Edwards, D. P., Gille, J. C., Drummond, J. R., and Nédélec, P. P.: Observations of near-surface carbon monoxide from space using MOPITT multispectral retrievals, J. Geophys. Res., 115, D18314, doi:10.1029/2010JD014242, 2010.

Worden, H. M., Deeter, M. N., Frankenberg, C., George, M., Nichitiu, F., Worden, J., Aben, I., Bowman, K. W., Clerbaux, C., Coheur, P. F., de Laat, A. T. J., Detweiler, R., Drummond, J. R., Edwards, D. P., Gille, J. C., Hurtmans, D., Luo, M., MartínezAlonso, S., Massie, S., Pfister, G., and Warner, J. X.: Decadal record of satellite carbon monoxide observations, Atmos. Chem. Phys., 13, 837-850, doi:10.5194/acp-13-837-2013, 2013a.

Worden, H. M., Edwards, D. P., Deeter, M. N., Fu, D., Kulawik, S. S., Worden, J. R., and Arellano, A.: Averaging kernel prediction from atmospheric and surface state parameters based on multiple regression for nadir-viewing satellite measurements of carbon monoxide and ozone, Atmos. Meas. Tech., 6, 1633-1646, doi:10.5194/amt-6-1633-2013, 2013b.

Zhang, L., Jacob, D. J., Bowman, K. W., Logan, J. A., Turquety, S., Hudman, R. C., Li, Q., Beer, R., Worden, H. M., Worden, J. R., Rinsland, C. P., Kulawik, S. S., Lampel, M. C., Shephard, M. W., Fisher, B. M., Eldering, A., and Avery, M. A.: OzoneCO correlations determined by the TES satellite instrument in continental outflow regions, Geophys. Res. Lett., 33, L18804, doi:10.1029/2006GL026399, 2006. 